\title{
The Development of E-commerce Software for MSMEs using the Agile Methods
}

\author{
Marike A.S. Kondoj \\ Department of Electrical \\ Engineering \\ Manado State Polytechnic \\ Manado, Indonesia
}

\author{
Herry S. Langi \\ Department of Electrical \\ Engineering \\ Manado State Polytechnic \\ Manado Indonesia
}

\author{
Yoice Putung \\ Department of Electrical \\ Engineering \\ Manado State Polytechnic \\ Manado, Indonesia
}

\begin{abstract}
Good software development requires a methodology as a reference or basis for achieving goals. This study aims to implement the Agile method to support the needs of MSMEs to provide tools in carrying out business processes. The results of this paper can be used as a consideration for the choice of the right software development methodology as needed.
\end{abstract}

\section{Keywords}

Metodologi, Agile, UMKM, Software

\section{INTRODUCTION}

In the new normal era, changes occur rapidly in the way consumers interact in business processes. In this case, to encourage every effort to reform business strategy. This study aims to implement the Agile method in developing ecommerce software to encourage MSME economic growth, especially MSME coconut products in North Sulawesi (SULUT).

MSMEs are one of the most affected by the coronavirus outbreak. The impact of the difficulty of doing business has resulted in many workers being forced to stay home. Therefore, technology plays an essential role in revitalizing MSME business continuity during this pandemic, apart from the government's efforts.

Two central problems faced by MSMEs affected by the pandemic, namely financial and supply problems. Apart from the lack of operational facilities, resources, and funding, MSMEs are still not optimal in mastering digital platforms. To overcome the problem of mastering technology, it is necessary to present software tools as an effort for MSMEs to survive in the time of a pandemic.

Success in developing software depends on how the overall project is managed. Choosing and determining the methodology used to design and build information system software is not easy. Every organization certainly has certain considerations, so that consideration is the key to determining methodology.

\section{RESEARCH METHODOLOGY}

Agile methods are used to develop e-commerce software for MSMEs based on the objectives to be achieved. The agile method was chosen as a reference in system development because the development time is quite short and costeffective. It allows rapid testing and deployment of applications. This study uses the Agile method's six stages, namely: planning, design, coding, testing, documentation, and deployment and maintenance.

\section{DISCUSSION AND RESULT}

COVID-19 has had a wide-ranging impact on the world's economy, including countries that dominate the technology market, with several countries closing stock markets, closing corporate offices, retiring small business workers, and canceling large social events.

The pandemic has brought down programmed business plans due to large-scale social restrictions. The most obvious impact is experienced by MSMEs whose business goals are only to make ends meet. Therefore, it is necessary to seek solutions to help MSMEs survive and develop in the new normal era.

The results of the survey released by Populix, during the pandemic, online shopping or e-commerce platforms became the people's choice in meeting their daily needs. The majority of people do work from home according to government recommendations and in North Sulawesi. People are increasingly fond of e-commerce, gaming, banking, automotive, entertainment applications, and so on.

From the results of several studies, during the Covid-19 pandemic in Indonesia, there was a significant spike in the pattern of using E-commerce by the community to meet needs. The increase was seen in the first quarter of 2020, which coincided with the emergence of the first cases of COVID-19 in Indonesia, and continued to increase in the second quarter by $38 \%$. This research is quantitative, where the data collection process uses the questionnaire method .

To accelerate software development based on Agile methods, the steps that have been taken include:

Planning: data collection and exit studies. At the data collection stage, the team made direct visits to MSMEs to obtain information related to the software needs they wanted to use to assist in running the business. In addition, studies related to e-commerce sites have been recognized by many people.

Implementation: do the coding based on the design. Several frameworks and templates are used in generating e-commerce web.

Testing: conducting software testing by prospective users as well as laboratory-scale testing.

Documentation: after testing, the system will be documented to facilitate maintenance in the future.

Deployment: test the quality of the system. If the system meets the requirements, then the software is ready to be deployed.

Maintenance: maintenance is important because no system is free from bugs. 
The results obtained are as in the figure below:

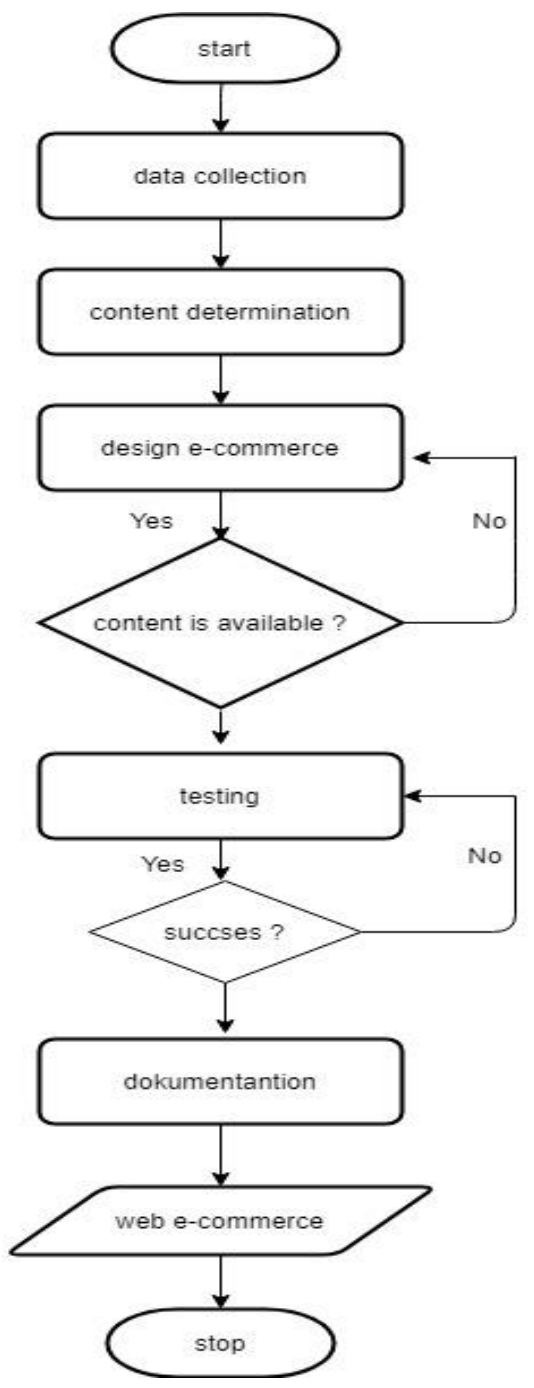

Figure 1. Conceptual framework

Agile software development is a software development method based on iterative work. The rules and solutions that each team member has agreed upon are carried out in a structured and organized collaboration.

At the lab-scale testing stage, we were found that several menus were running not following the expected results, including testing the QR code for web pages. The link that is read still refers to the localhost address while the system is online. The step taken is to update the data link displayed to match the address shown to identify the web page.

Documentation is done by compiling the design stages until a lab test is carried out to produce a module containing the steps for system development.

The design of the E-commerce model for MSMEs for coconut-derived products based on the website is to help and make it easier for consumers to make purchases of coconutderived products. Based on observations, no official website provides buying and selling transactions for coconut-derived products in North Sulawesi. Therefore, a system requirements analysis must be carried out to create a solution during a pandemic with the help of tools or software that has features that can make it easier for users and business owners to make buying and selling transactions. The interface design (home) based on the conceptual framework is:

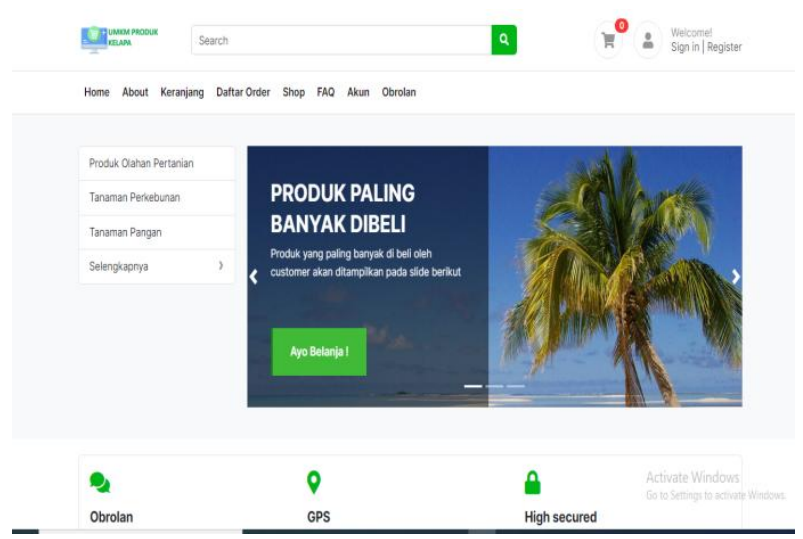

Figure 2. Home

Users can choose the desired product even the system presents the most purchased product information. Other features available are that the customer can communicate with the seller/owner via chat. The GPS feature for the seller/owner can enter a more accurate location, allowing the customer to pick up their product or buy directly. For security, customer, buyer and transportation data are not disseminated.

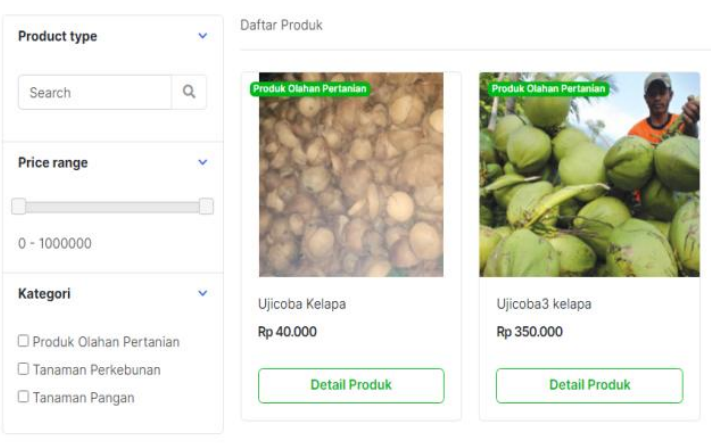

Figure 3. User Dashboard

The web test was carried out to 50 respondents related to accessing and using the features. The test results showed $57.7 \%$ strongly agree if it is easy to use, $21.6 \%$ agree, and $20.7 \%$ disagree and provide input for web improvement.

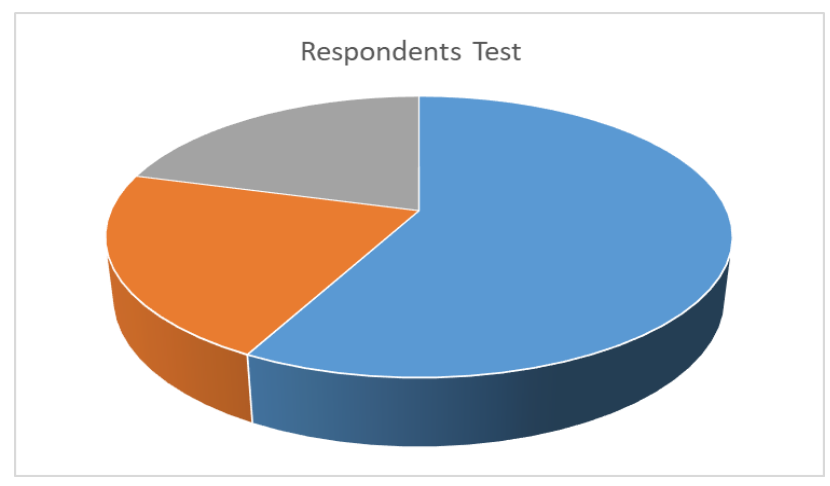

Figure 4. Respondents Test

\section{CONCLUSION}

E-commerce software development is very suitable for using the Agile method because this research produces software quickly and in small teams. Who chose agile methods because various parties can feel the benefits. After all, communication 
is often done to achieve goals. Moreover, the web developed is straightforward to use based on the results of the respondent's test.

\section{ACKNOWLEDGMENTS}

Thank you to all who took part in this research and the Ministry of Education, Culture, Research and Technology, who have supported the financing of this research activity.

\section{REFERENCES}

[1] Liaukonyte, J., Teixeira, T., \& Wilbur, K. C. (2015). Television advertising and online shopping. Marketing Science, 34(3), 311-330.

[2] Carlsson-Szlezak, Philipp, Martin Reeves, and Paul Swartz. 2020. What Coronavirus Could Mean for the Global Economy. Harvard Business Review, 3.

[3] Cohen, D., Lindvall, M., \& Costa, P. (2004). An introduction to agile methods. Adv. Comput., 62(03), 166.

[4] Chang, H. H., \& Meyerhoefer, C. D. (2021). COVID-19 and the demand for online food shopping services: Empirical Evidence from Taiwan. American Journal of Agricultural Economics, 103(2), 448-465.

[5] Kondoj, M. A., Sundah, D., \& Sawidin, S. Analysis of Consumer Behavior in the Use of Online Shop with the
Fuzzy Logic Tahani Method in Manado City Indonesia. International Journal of Computer Applications, 975, 8887.

[6] Lohse, G.L., Bellman S. and Johnson, E. J., "Consumer Buying Behavior On The Internet: Findings from Panel Data", Journal of Interactive Marketing, Vol.14, No. 1: 15-29, 2000.

[7] Shanthi, R., \& Desti, K. (2015). Consumers' perception on online shopping. Journal of Marketing and Consumer Research, 13, 14-21.

[8] Suliyanto, S. E., \& MM, S. (2017). Metode Penelitian Kuantitatif.

[9] Rakhmawati, N. A., Permana, A. E., Reyhan, A. M., \& Rafli, H. (2021). Analisa Transaksi Belanja Online Pada Masa Pandemi Covid-19. Jurnal Teknoinfo, 15(1), 3237

[10] Khan, A. G. (2016). Electronic commerce: A study on benefits and challenges in an emerging economy. Global Journal of Management and Business Research.

[11] Khan, A. G. (2016). Electronic commerce: A study on benefits and challenges in an emerging economy. Global Journal of Management and Business Research 